Dan Rabinowitz and Daniel Monterescu

\title{
RECONFIGURING THE "MIXED TOWN": URBAN TRANSFORMATIONS OF ETHNONATIONAL RELATIONS IN PALESTINE AND ISRAEL
}

Identifying ethnonational mixed towns as an analytical and comparative category, we show how in Palestine and Israel such towns underwent six major historical transformations and how their history under Ottoman, British, and Israeli rule displays an emergent and bifurcated sociospatial configuration. On one level, they personify the political conflict over space and identity as it evolved from millet-based confessional communities to modernist nation-based collectives shaped by milestones of the Palestinian-Israeli conflict. On another level, they form political and cultural arenas that defy the binary logic of ethnonationalism and urban colonialism. Avoiding the restrictive Manichaean conceptualizations of the colonial, the divided, and the dual city, we show how such towns embody segregation and exclusion while actively resisting them. Scrutinizing demographic diversification, cultural expansion, intercommunal relations, and the secularizing, modernizing effect urbanity has had in the region, our analysis, which emphasizes relationality, reconfigures the sociospatial history of Jewish-Arab mixed towns. 